with Europeans since the end of the sixteen:h century. M. Hamy referred in detail to the manners and industry of this people. (4) This is a slightly heterogeneous group, consisting of the Obambas, Ondumbas, \&c., who live in the neighbourhood of Franceville. In conclusion the speaker referred to the interest of ethnological research in relation to the movements of peoples on the earth's surface. Here, he said, ethnography is especially bound up with geography.

THE Portuguese explorers, Col. Serpa-Pinto and Lieut. Cardoza (according to the Colonies and India) recently left the Cape Colony for Lisbon. These gentlemen have accomplished a most important scientific exploration in the Lakes region. Leaving Mozambique, they proceeded by land to Ibo, correcting many errors that had crept into the charts. From Ibo they advanced to Nyassa at the head of an Expedition 800 men strong, making as they went a geodetical triangulation of the country, using instruments of great precision. Col. Pinto, in consequence of a dangerous attack of illness, was obliged to leave the Expedition in Mebe's country, of which he had made a geological survey, occupying a long time. Lieut. Cardoza, who had been blind for fifty days, happily recovered his sight in time to take the command of the Expedition, continuing the work to Nyassa, from whence he went to Shirva and Blantyre, and by a new road to Quilimane. The whole party suffered from hunger on the way; all the dogs died of starvation, and the men narrowly escaped the same fate. The Expedition was accompanied by 200 Zulus, who rendered splendid services, being conspicuous for their courage and devotion. Besides their scientific work, the first of the kind done in that part of Africa, the leaders of the Expedition extended the Portuguese dominion over all the important chiefs visited during the journey, lasting twenty months. Everywhere the Expedition was heartily welcomed by the natives, the only place where the Mission was not cordially received being, it is said, the Blantyre Mission Station.

THE September issue of the Scottish Geographical Magazine contains a paper by Prof. Meiklejohn on the history, poetry, \&c., in geographical names. Mr. Murray, of the Challenger Expedition, reviews the existing state of our knowledge of the Antarctic regions $a$ propos of the project for exploring them. The Council have unanimously resolved to support any movement having for its object the careful exploration of the Antarctic regions, "as being certain to result in large and important accessions to our knowledge in geography, oceanography, meterrology, and other branches of physical science." They think the expedition should be undertaken at Government expense, but the co-operation of Australasian Governments might be invited. They suggest a conference of delegates of the leading scientific Societies to draw up a memorial to the Government on the subject.

ACCORDING to the latest intelligence received at Zanzibar from the interior of Africa, Dr. Wilhelm Junker, the African traveller, was at Msalala, south of the Victoria Nyanza, and was about to start for Zanzibar. Emin Bey was still at Wadely, and was in urgent need of supplies of ammunition and stores. The King of Uganda had murdered all the English and French converts, and the missionaries were in great danger and had asked for assistance.

Prof. Blumentritt contributes to the last number of Globus (vol. 1. No. 14) an interesting article on the Manguians of the island of Mindoro, in the Philippines, based on a Spanish work by Don Morera on the geography and natural history of that archipelago. Next to Luzon and Mindanao, Mindoro contains the greatest number of wild tribes. Those which live on the coast and along the banks of the rivers are known under the general name of Manguians, while the Bangot inhabit the plateans, and the Buquil and Beribi have their villages amongst the high mountains of the interior, but these names vary greatly in different parts of the island. They exhibit a mixture of various races. Besides the Malay;, there is Negrito blood in the Buquils, and in some places traces of Chinese descent also. Prof. Blumentritt confines himself to describing the manners, customs, dress, \&c., of the Manguians. Incidentally, however, the paper tends to show the enormous complication and difficulty of ethnological questions relating to the Philippine Islands. The constant mingling of different races from China, Malaya, and parts of Melanesia and Polynesia has created a mixture of which the component parts are almost undiscernible. The vast variety of names given to tribes, which rarely mark any ethnical distinction, and which sometimes are-given to the members of the same tribe, add to the confusion.

\section{NOTES ON VESUVIUS FROM FEBRUARY 4 TO AUGUST 7, I886}

I N NAture (vol, xxxiii. p. 367) I gave a description of the changes that had taken place in Vesuvius during the preceding months, and of the eruption of February 4. The lava that issued on that occasion continued to flow in abundance until the rith, forming a brilliant streak on the northern slope of the cone. After that date the output of fused rock varied at intervals till about the end of the third week in March, when the outflow stopped.

On April 21, at about 5 p.m., lava rose from that portion of the fissure crossing the great crater plain on its south side, and which was the one by which the eruption of May 2, I885, had taken place. The quantity that oozed out was comparatively small, and sufficed only to flow down the side of the great cone for about roo metres, so as to just cover the point of exit of the lava that had issued from the same fissure in the spring of 1885. The new lava piled itself up into a kind of boss, and thus soon plugged its own passage.

A few days after, that is, on April 27, a new outburst occurred, again at a weak point-the upper limit of the fissure of I $881-82$, above the buttress of lava formed subsequent upon that eruption. This was sufficient to carry off the overflow for some weeks. Slight variations, such as are constantly going on, were observable in the activity of Vesuvius and the outflow of its lava during the whole of the month of May. During the eruption of Etna, Vesuvius did not show the slightest sympathy -just what we should expect when our conception of a lateral outburst is that it is simply a mechanical result of changes that proceed in the upper part of the volcanic chimney, and usually of the mountain itself.

During the month of June the outflow of lava on the eastern side persisted, adding to the great boss, hump, or buttress formed during the years subsequent to the eruption of $1881-82$. Owing to the height of the lateral outlet, and probably also from its narrowness, the level of the lava column in the chimney was very high, and, as a consequence, the numerous pasty lava-cakes added much to the size of the eruptive cone, which grew so rapidly during the month as to cover all the old remnants of crater-rings except a small portion of the northern rim of that of I88 r -82. On June 29, when I visited the crater, I found a long continuous fissure extending right across the great crater plain in a westerly direction, and emitting an abundance of hot air, $\mathrm{HCl}$, with vapour of chlorides, which were deposited in feathery bunches on the cooler edges of the fissure. This fissure no doubt corresponds to the upper limit of a radial dyke, as did the one existing for many months previous to the eruption of May 2, 1886, and probably does, like that one, indicate the direction of an eruption at some future time. When such an eruption takes place it will be unpleasant for the funicular railway, which, although a little south of the line of fissure, would be within reach of the outburst. In the above-mentioned visit it was possible to watch the eruptive mouth for some time from the edge of the cone of eruption, and to take an instantaneous photograph of it amidst an exciting bombardment of stones, not dangerous for one's self, but unfavourable to an inactive phutographic camera. Unfortunately an accident happened to the negative, but I have since been successful in obtaining a permanent record of the eruptive mouth, though hardly such a successful picture. The diameter of the main vent was about 3 or 4 metres, and nearly circular.

The crater was again visited on June 5, but no marked change had taken place, and lava was always issuing on the east side and flowing first to one side and then to the other, always adding to the great buttress.

The cone of eruption, owing to its great increase of size during the last thirteen months, formed a very conspicuous mound, perched as it were on the flattened summit or crater plain of 1872 , which truncates the great cone of Vesuvius. On June 28 it was observable from Naples that the cone was falling in, and the spine or boss forming the northern boundary of the crater of eruption had in part disappeared, and owing to the plusging of the passage the smoke only escaped in puffs. This crumbling in of the crater walls was no doubt due to the loss of 
support of the column of lava within the chimney. This lowering of level probably produced the extension outwards of the eastern dyke, and the lateral outlet of lava was consequently lowered. This was confirmed by the much increased outflow of lava coincident with the falling in of the cone.

During the first week in July the volcano appeared from Naples to be very quiet; indeed, less vapour was escaping from the summit than at any time during the last seven years. From time to time the vapour was, from the gradually increasing pressure, able to burst its way through the loose materials that choked the outlet, when a puff of smoke would be visible of a dark purplish-black colour, due to its being charged with volcanic ash derived from the churning up and trituration of the lava fragments, scoria, and lapilli it had to traverse in its escape. At the same time a slight reflection was to be seen at night, indicating that the lava surface, although lowered, was not so to any great extent.

On this day, July 8 , the lava which had always been gradually advancing, had crossed the southern end of the Val d'Inferno, and flowing down one of the wooded ravines on the property of the Prince of Ottajano, where it destroyed a number of trees, it continued its course, overwhelming some vine gardens. On July 12 the number and quantity of the black smoke puffs was very great, and the crater was in the full ash-forming stage, and towards night the vent had been considerably cleared, so that the reflection was well marked. The next day the smoke issued freely and uncharged with ash. The change that took place on the 12th was no doubt due to the lava rising in the chimney consequent upon the lateral outlet getting choked; as on the I Ith, the abundant flow of lava became very much diminished.

On July 20 the puffs of dark smoke again appeared, indicating a return of the crumbling in of the crater ; this was again due to the lowering of the lava level, and, as was expected, the fluid rock issued in great abundance the following day, again destroying trees and vine-gardens. The next day the lava was still flowing in abundance, so as to form a bright streak on the slope of the great cone. The outflow continued to gradually diminish until the 3 oth, the crater above remaining inactive. On the latter date, however, the lava rose again sufficient within the chimney to cause the vapour to find a passage through the materials choking the main vent, so that on that day the puffs of black smoke were again abundant, and accompanied by the ejection of partially triturated subangular old lava and scoria fragments. In the evening bright bursts were well marked, showing that the vent was again cleared. The two following days the volcano maintained the third degree of activity Rep. Brit. Assoc., 1885, p. 395).

During the first week of August the lava again flowed rather freely from the mountain's side, whilst from its summit hardly any vapour escaped except from time to time a puff of blaek smoke. On August 7 a visit was paid to the crater. The cone of ertuption has been reduced in height about 30 metres, and its remnants form a low crater ring inclosing a crater of oblong form having a diameter of about $80 \times 60$ metres. Its greater axis lies in a line from about E.S.E. to W.N.W., and its bottom is double, so that it seems to result from two craters closely overlapping each other. The crumbling-in process was still going on, and the trituration of the loose stones and the charging of the vapour puff by the ash or sand could be watched from a distance of a few yards. I was successful in obtaining two ordinary and two instantaneous photos of the interior of the crater, only the eastern half of which, however, was active.

The principal facts that may be gathered from the study of the phenomena of Vesuvius during these few months are rather confirmations of what the author has described as the mechanism of lateral eruptions, which may be summed up thus. The lowering of lava level within the chimney due to a lateral outlet removes the support the former gave to the walls of the crater and vent, which in consequence tumble in and choke more or less of the main outlet. Next the vapour contained in the lava may be compelled to escape laterally, but has a natural tendency not to do so, but rather to seek its path straight upwards. If the lateral outlet becomes choked, the lava immediately com. mences to rise in the chimney, and the escaping vapours burst through the loose materials in the chimney in puffs, grinding and triturating them, carrying upwards their dust, which tints the smoke of a dark colour, and, falling around the volcano, constitutes one of the forms of "volcanic ash," the chemical composition of which represents that of all the rocks triturated plus the saline substances condensed from the smoke. If one walks across this ash when damp, one may notice the immediate plating of their boot-nails with copper, showing the abundance of the chloride of that metal.

H. J. Johnston-LAvis

\section{THE ADELAIDE BOTANIC GARDEN AND GOVERNMENT PLANTATION}

THE report of Dr. Schomburgk on the progress and condition of the Botanic Garden and Government Plantation, Adelaide, during the year 1885 has just reached us. Speaking first of the rainfall, Dr. Schomburgk says that the year was one of the driest and most ungenial that he ever had to contend with, the rainfall being no more than 15.887 inches, which was $2.85 \mathrm{I}$ irches less than the fall of 1884 , and 5.272 below the average rainfall during the previous forty years. During September, October, November, December, and January no more than 3 inches of rain fell, and the lieat during these months was abnormally great. The drought and heat combined had an injurious effect upon the vegetation, especially upon many of the trees and shrubs in the Botanic Garden, natives of cooler countries; the losses sustained, however, were not so great as was expected, owing to an abundant supply of water. On the other hand, in May and June severe frosts were experienced, so that tropical and sub-tropical plants and shrubs suffered greatly.

On the question of the introduction and acclimatisation of new economic plants, Dr. Schomburgk records his experience with many that have been widely distributed through the agency of the Royal Gardens, Kew, and have become known and esta. blished in other colonies as well as in India, such, for instance, as the Kumara (Ipomaa chrysorrhiza), the tubers of which form an article of food in New Zealand. Dr. Schomburgk says he believes that the plant will grow well in the gullies, because the climate there is cooler and moister than on the plains, and to some extent approaches that of New Zealand. The Gingelly oil plant (Sesamum indicum) is also reported upon favourably. The seeds were sown in drills in the open ground in October, and came up in about fourteen days. Considering that neither the dry spring nor the summer heat affected the plants, there seems no doubt that the species can be successfully cultivated in South Australia. The plant is an annual, and is very largely grown in warm countries for the sake of the sweet limpid oil now so much used for mixing. with olive oil.

Under the head of Rhopala sp. an announcement is made of the receipt from Kew of a parcel of seeds of a tree belonging to the above-named genus, a native of Columbia, with the following extract from a letter of Mr. W. T. Thiselton Dyer:- "The Rhopala is a small contorted tree growing to about twenty feet in height. It is remarkable for being absolutely indestructible by fire, in large districts where the dry pastures and bush are burnt twice a year. Its resistance to fire enables it to exist to the exclusion of all other trees and bushes as a perfect natural plantation. The periodical burning destroys everything except this tree. The resemblance to a plantation is moreover enhanced by the circumstance that the trees never form thickets, and they are thickly and almost systematically dispersed over the land. The tree delights in the most sterile soils, but always of a stony or shingly character. Sometimes it grows in places so barren that even grass cannot exist. This suggests the idea that it may be turned to account in sterile districts within the tropics." Dr. Schomburgk expresses some doubt whether the plant will thrive out of doors with them, but thinks it may do well in the Northern Territory.

The Herbarium and Museum have both been considerably enriched by additional specimens during the year, so that the utility and efficiency of the whole establishment are thoroughly maintained.

\section{THE AMERICAN ASSOCIATION}

F ROM the report in Science of the Buffalo meeting of the American Association we condense the following brief summary :-

Prof. Gibbs's masterly address, in the Section of Mathematics and Astronomy, upon the subject of "Multiple Algebra," was too long and of too technical a nature for presentation in full to our readers. His opening remarks were as follows :-

"It has been said that "the human mind has never invented a labour-saving machine equal to algebra.' If this be true, it is but natural and proper that an age like our own, characterised 